\title{
MLL/MLLT1 Fusion Protein
}

National Cancer Institute

\section{Source}

National Cancer Institute. MLL/MLLT1 Fusion Protein. NCI Thesaurus. Code C99322.

A fusion protein encoded by the MLL/MLLT1 fusion gene. This protein is comprised of the $\mathrm{N}$-terminal half of the histone-lysine $\mathrm{N}$-methyltransferase $\mathrm{MLL}$ protein, including the AT hook DNA binding domain and the DNA methyltransferase domain, fused to almost the entire protein ENL. 